\title{
NotAS SOBRE A MIMESIS EM RUY DUARTE DE Carvalho, leitor de Guimarães Rosa
}

\author{
Anita Martins Rodrigues de Moraes \\ anitademoraes@gmail.com
}

Gostaria de iniciar estas considerações sobre a mimesis, mais precisamente, sobre a representação do outro e de sua fala em Ruy Duarte de Carvalho, leitor de João Guimarães Rosa, notando que a continuidade/ descontinuidade entre os discursos do autor, do narrador e de personagens consiste em relevante questão de composição literária que abarca, necessariamente, problemas éticos e políticos. Trata-se, pareceme, de assunto fulcral no âmbito das teorias da narrativa do século XX, particularmente no que se refere ao romance. Tenho em mente a teoria do romance de Mikhail Bakhtin, mas não só. A atenção para as relações entre discursos e pontos de vista no tecido narrativo caracteriza também reflexões tão diversas como as de Norman Friedman e Theodor W. Adorno. ${ }^{1}$ Cada teórico, à sua maneira, lida com o mesmo problema das hierarquias (e ruptura de hierarquias), distâncias e zonas de intersecção e fricção entre os discursos do narrador, de personagens e do autor. No 
entanto, é muito precocemente que o problema da representação da fala alheia se coloca.

A imbricação entre modos de representação e problemas de ordem ético-política se encontra, surpreendentemente, já delineada na condenação platônica da poesia mimética. A fala que emana da boca da personagem num poema épico ou dramático abriga, para Platão, graves perigos, devendo ser controlada. No livro terceiro d'A República, o filósofo grego defende (interessantemente, em discurso que sai da boca de Sócrates) que, ao dar voz às personagens, o poeta se envolve em atividade das mais arriscadas: buscando se assemelhar às personagens para representá-las, pode aderir às suas maneiras.

Ao apresentar sua preocupação quanto às consequências deste se voltar do poeta ao modo de falar das personagens, Platão nos remete a Homero. O exemplo que traz é conhecido: na Ilíada, caso apenas contasse como Crises agiu e, indiretamente, relatasse o que se passou, o poeta não se aproximaria do ancião, manteria segura distância; mas o que faz Homero é dar a palavra a Crises, e, então, busca representar/ imitar sua fala. Aqui estaria, na perspectiva platônica, o risco: ao construir tal fala, Homero se cala e finge que é outro, silencia a si e fala uma fala alheia, que ele próprio inventa por meio da mimesis (imitação/representação); ao falar como outro, imitando-o, finge ser o que não é, e pode vir a se tornar o que imita, aderindo ao fingimento, incorporando-o em sua própria vida. Existiria, assim, uma espécie de risco de contaminação envolvendo a mimesis, além da suspeita de que o querer (e conseguir) representar/imitar certo modo de ser delate já certa predisposição do poeta.

A mimesis, o modo mimético/imitativo, surge, na fala do Sócrates platônico, em relação de contraste com a diegesis, ou modo diegético/ narrativo. Ao narrar, o poeta se manteria como é, sua fala coincidindo com aquela que emana da sua própria boca. Não haveria, no modo diegético, esse fingir ser o que não se é. Representar ou imitar a fala das personagens parece envolver um deslocamento, um movimento ao outro de que a narração protegeria. Ao representar/imitar o outro, o poeta se lança para fora de sua pessoa, podendo retornar dessa experiência modificado. Eis o problema: como garantir que a mudança possibilitada pela mimesis não seja danosa?

Na perspectiva de Platão, há elementos que nos levariam a esperar danos. A mimesis envolveria experiência emocional intensa, atrofiando a 
parte racional da alma (ou do Sujeito)² e arriscando comprometê-la. No mesmo livro terceiro, Sócrates afirma que o maior problema do poeta mimético (aquele que tudo imita) é a falta de discernimento acerca do modelo que merece ser representado/imitado. Com um adendo: além de colocar-se em perigo por se mover em direção àquele que será objeto de imitação, o poeta mimético expõe seus ouvintes/espectadores aos mesmos riscos, pois também os aproximará dele. Poeta e público se envolvem numa metamorfose momentânea, que pode ser irreversível: deixando de ser quem são para se assemelhar ao outro, dão vazão a emoções que, em sua vida mesma, desconhecem ou buscam reter.

Os perigos da mimesis envolvem, para Platão, deslocamento, aproximação do outro, aderência, contágio, descontrole emocional e perda da razão. Interessantemente, o modo narrativo surge como mais seguro, garantindo distância e permitindo discernimento crítico (racional) acerca do modo de ser das personagens. A mimesis - seja na fala das personagens numa narrativa, seja numa peça de teatro - lançaria a todos (produtores e receptores) numa estranha e arriscada experiência de ser para além de si, de deixar de ser a si, para se aventurar em um modo de ser alheio. O perigo está na fala do outro, o momento da mimesis é o momento da representação da fala alheia.

Gostaria de considerar ainda um aspecto da discussão platônica: a indistinção entre pessoa/autor/narrador na figura convergente do poeta. Por um lado, a aposta de continuidade simples entre pessoa/ autor/narrador nos confrange. Afinal, os esforços teóricos do século XX foram justamente os de discernir estratégias de composição narrativa, destacando a natureza discursiva do narrador (que surge como "voz" e como "foco", como "ponto de vista") e problematizando a noção de autoria (que se faz também uma realidade discursiva, não coincidindo

\footnotetext{
2 Alain Badiou, em seu estimulante $A$ República de Platão (recontada por Alain Badiou), reescreve o texto platônico recorrendo ao termo Sujeito ao invés de alma (2014, p. 14). O trabalho do pensador marroquino converge com os esforços do presente ensaio: lidar com a energia reflexiva do texto platônico, fazê-lo vibrar e propiciar a gestação de ideias no presente, deslocando-o tanto de seu contexto de origem como do peso (porvezes sufocante) de certas leituras já cristalizadas. Empenho-me, assim, em lidar com as noções de mimesis e diegesis como as entendo concebidas no livro terceiro d'A República, mantendo distância com relação a formulações teóricas de certa narratologia novecentista, particularmente no que se refere às proposições já muito conhecidas de Genette (2011).
} 
com a pessoa do autor). ${ }^{3}$ Por outro lado, se pensarmos nos perigos da mimesis, na desestabilização que pode, segundo Platão, provocar, uma interessante ideia acerca da pessoa (do que é ser uma pessoa) se insinua. Se fossemos, os seres humanos, definitivamente, se ao nos constituirmos como pessoa, o fossemos de modo estável e acabado, não haveria perigo. Se há perigo na experiência mimética, é porque nossa condição existencial é instável. Ou ainda: se há experiência mimética é justamente porque não somos o que somos de uma vez por todas.

Retornando ao livro segundo d'A República, vemos que a preocupação primeira de Sócrates é a da formação de jovens. Em sua perspectiva, cresciam ouvindo histórias mentirosas - nos poemas de Hesíodo e Homero, especialmente - e sua formação se via, então, comprometida. O que me interessa destacar é: tornar-se uma pessoa parece envolver a imitação de modos de ser, envolve representar papéis (assumir/incorporar certos modos de comportamento), faz-se, portanto, já por uma espécie de mimesis. Podemos avançar e entender que a forma humana, o modo de ser de uma pessoa, faz-se num jogo entre a disposição a representar papéis e os modelos disponíveis. Mas mesmo os adultos, supostamente formados, estariam sujeitos a metamorfoses. É curioso que a característica distintiva dosdeuses seria, segundo o Sócrates de Platão, sua imutabilidade. Perfeitos, não mudariam de forma. O humano, contudo, em sua precariedade, surge inconstante, vulnerável, matéria inevitável e perigosamente plástica. É aqui que a poesia mimética, com seus riscos, se instala. ${ }^{4}$

Pretendo valer-me de aspectos da condenação platônica da mimesis (ou melhor, da leitura que faço de passagens d'A República, de Platão)

3 Quanto à autoria, tenho em mente especialmente a concepção de Bakhtin (o autor como espécie de maestro que dispõe as falas no romance; 2013) e de Foucault (o autor como "função do discurso" delineando, em certas sociedades, hierarquias e classes discursivas; 2010). Já com relação ao narrador, penso em Friedman (2002) e novamente Bakhtin (2013). 4 Plasticidade humana e mimesis se associam desde as teorizações iniciais de Luiz Costa Lima, cujo diálogo com Iser é já então patente e fecundo (ler os ensaios "Representação social e mimesis" e "Persona e Sujeito ficcional"). Vale notar que a antropologia literária de Iser propõe justamente a "plasticidade" como traço humano geral evidenciado pela literatura (ler especialmente $O$ fictício e o imaginário: Perspectivas de uma antropologia literária). 
para refletir sobre a representação do outro e de sua fala na obra de Ruy Duarte de Carvalho, destacando seu diálogo com a obra de Guimarães Rosa. É o próprio Ruy Duarte de Carvalho quem me auxilia na definição deste outro. Em seu texto “Tempo de ouvir o 'outro' enquanto o "outro" existe, antes que haja só o outro... Ou pré-manifesto neo-animista”, de 2008, defende que a expansão do modo de vida ocidental, implicada em processos coloniais, teria produzido diferentes outros. Destaca três:

\begin{abstract}
.....considerarei aqui como OUTRO, sublinhado ou em itálico, os indivíduos e os grupos, muitos deles já nascidos ou constituídos no território das exmetrópoles a partir de genitores ex-colonizados ou provenientes de ex-colónias e que hoje integram, de pleno direito estatutário, as populações nacionais dessas mesmas ex-metrópoles embora reconhecidos como diferentes da massa dominante através de traços fenotípicos ou culturais......... como 'OUTRO', entre apóstrofos, o ex-colonizado ocidentalizado com que o ocidente lida nos contextos das ex-colónias........ e finalmente como "OUTRO”, entre aspas, aquele sujeito marcado por traços afetos a populações que, integradas embora como nacionais em estados-nação que hoje existem a partir de contornos excoloniais, mantêm usos, práticas e comportamentos mais afins a quadros précoloniais do que pós-coloniais ou mais ou menos ocidentalizados.........
\end{abstract}

Os três outros delineados são outros em relação ao colonizador e seus descendentes, estes habitando o espaço do próprio, do não marcado. Em situação colonial, a relação próprio/outro surge homóloga à oposição norma/desvio (participar da norma coincidiria com a participação em padrões de adequação estabelecidos pela civilização ocidental e impostos nos processos coloniais e neocoloniais). O próprio, o eu, seria aquele que assume uma fala tida por competente, ou seja, aceita como correta; o outro (mais ou menos distante deste centro de que emanaria a norma) teria uma fala marcada - sendo o ele do eu que detém a fala, e não o tu.

Minha proposição é a de que podemos pensar a representação das falas numa narrativa em termos de representação de discursos reconhecíveis socialmente. Ou seja, aproximando-me de Bakhtin, entendo que o discurso do narrador e das personagens serão representações de formações discursivas disponíveis, arranjadas de modo particular no tecido narrativo, permitindo-se sua visibilização.

5 Este texto está disponível no site Buala: <http://www.buala.org/pt/ruy-duarte-decarvalho/tempo-de-ouvir-o-outro-enquanto-o-outro-existe-antes-que-haja-so-o-outroou-p>. 
Esta possibilidade, defendida por Bakhtin como traço característico do romance, de friccionar os discursos tornando-os reconhecíveis, ou seja, transcendendo seu próprio domínio (do contrário, haveria adesão e reprodução simples e inconsciente dos modos discursivos vigentes), ${ }^{6}$ tem, parece-me, desdobramentos ético-políticos claros: tornando opaco o discurso tido como competente, fazendo-o coabitar com discursos diversos, abalam-se as hierarquias instituídas. Haveria, na mimesis, na representação da fala alheia, uma força de desordem. Se no arranjo dos discursos representados num romance as hierarquias vigentes são desrespeitadas, este mesmo romance se torna uma instância de corrosão da ordem estabelecida; se, ao contrário, a organização dos discursos repõe, internamente, as hierarquias sociais vigentes, o romance em questão seria agente de reprodução da ordem (ou reprodução irrefletida da doxa). ${ }^{7}$

João Adolfo Hansen, na conclusão de seu estudo sobre Grande sertão: veredas, defende ser neste romance de Guimarães Rosa que, pela primeira vez, "falam as linguagens do mato" (2000, p. 191). Explica o estudioso:

falam as linguagens do mato sem mediação de narrador ilustrado que, na ficção brasileira, sempre usurpou o lugar de fala do sertanejo, quando o constituiu como natureza, idílica ou decaída, como outro inalcançável ou a ser convertido, ou, ainda, como outro tristemente alienado nas garras do capital (...). Se a fala de Riobaldo unifica em seu movimento de fala a velha dicotomia litoral/sertão, emblema-matriz de outras dicotomias da mesma espécie com que o Brasil já foi pensado - e é até hoje -, tal dicotomia vai sendo deslocada: pois em sua fala o doutor ilustrado está emudecido à força enquanto o discurso se apropria macunaimicamente das Luzes fazendo-as falar pelo avesso, nos efeitos de inépcia fingidíssima, seu lugar e interesses datáveis. (HANSEN, 2000, p. 191).

6 Remeto o leitor a "O discurso no romance", parte do volume Questões de literatura e estética, de Bakhtin (1998).

7 Nesta recuperação de aspectos das proposições de Bakhtin, recorro a momentos da teorização de Luiz Costa Lima acerca da mimesis, valendo-me de sua ideia de "perspectivação" (ver Mimesis: desafioao pensamento). Efeito da mimesis, a perspectivação resultaria justamente do reconhecer as semelhanças e as diferenças entre o produto mimético e o que se supõe ser o mundo real. Se pura semelhança, não haveria mimesis e sim reposição do mundo mesmo (ou seja, dos discursos naturalizados de que é feito). Para haver mimesis, como propõe Costa Lima, é preciso haver, sobre um fundo de semelhança, diferença. Vemos que o teórico entende que a irracionalidade da mimesis apontada por Platão seria seu funcionamento incompleto, de pura semelhança (reposição), e aposta noutro funcionamento, que seria o da mimesis plena, envolvendo também o jogo da diferença. Importa, ainda, reter que, para o teórico brasileiro, a experiência mimética se realiza na recepção. 
Segundo Hansen, Rosa "faz personagens os que, como um impensado, a cultura desqualifica como irrepresentáveis, pois irresponsáveis, sem competência para falar (...)" (2000, p. 65). Esta fala do outro tem força questionadora, evidencia "os limites do discurso tido como de bom senso, o universal, adaequatio orationis ad rem" (2000, p. 65). A fala de Riobaldo incorpora discursos reconhecíveis, perspectivando-os; desloca dicotomias basilares (litoral/sertão; civilização/barbárie), produzindo abalos no discurso ilustrado, socialmente legitimado como competente e adequado (adequação e competência surgem com contornos, particularizadas, evidenciando-se a falácia de sua universalidade). Esta força questionadora resulta das estratégias de composição do romance, da construção de um narrador-personagem sertanejo, ${ }^{8}$ cuja fala se produz em situação de diálogo com um "senhor doutor". A suposta fala do senhor doutor, que não se faz ouvir, é perspectivada (para o leitor) ao ser incorporada dialogicamente no discurso do sertanejo: "o sertão fala rosnando, bestíssimo, pois relativiza, apaga as falas exteriores que lhe impõem silêncio, e relativiza também a sua própria fala, pois não a avança como única" (2000, p. 193). Hansen delineia noções como "linguagens do mato" e "falar/rosnar do sertão". Trata-se de sugerir a perturbadora representação de uma fala alheia aos padrões legitimados (de pensamento, comportamento, correção linguística). Quem fala uma "linguagem do mato"? Estaríamos diante daqueles outros delineados por Ruy Duarte de Carvalho?

Em 2006, Ruy Duarte de Carvalho publicava Desmedida: crônicas do Brasil, uma espécie de relato de viagem pelo rio São Francisco. Para falar desta viagem, recupera leitura de Guimarães Rosa: o que é visto e ouvido (tantas falas dos que habitam as margens do rio) se adere à palavra rosiana, palavra esta que se repõe a todo o momento no livro (em inúmeras citações, muitas delas não marcadas). ${ }^{9}$ Assim, o que é possível aos olhos

8 Antonio Candido também destaca a relevância do foco narrativo em Grande sertão: veredas (1977, p. 156).

9 Na edição brasileira, pp. 116, 117, 128, 129 e 130, por exemplo. 
ver é desdobramento de escuta e leitura, surge já como amálgama da palavra do outro com a própria, o olho se inscreve em viva dinâmica de boca e ouvido, por ele a palavra e a luz atravessam, já em composto inextricável. Vejamos como o primeiro encontro com a obra de Rosa é narrado:

Quando aí por 1965, numa tabacaria da Gabela, interior do Kwanza-Sul, dei encontro com o Grande sertão: veredas em edição, a $5^{\mathrm{a}}$ parece-me, da Livraria José Olympio, o facto foi, de facto e de várias maneiras, muito importante na minha vida. Foi um daqueles livros que vêm, literalmente, ao nosso encontro (...). (...) Defrontei-me então muito arduamente com as primeiras páginas do Grande sertão e deixei-me depois entrar naquilo para tornar-me, a partir daí e até agora, um leitor compulsivo, permanente e perpétuo, de Guimarães Rosa. (...) Mas para o que talvez possa interessar agora, eu estava a encontrar ali, finalmente, um tipo de escrita e de ficção adequadas à geografia e à substância humana que eu andava então, técnico da Junta do Café, a freqüentar e a fazer-me delas por Angola afora. (...) E nas paisagens que Guimarães Rosa me descrevia, eu estava a reconhecer aquelas que tinha por familiares. Já porque de natureza a mesma que muitas paisagens de Angola - e em algumas das paisagens de Angola eu reconhecia aquelas, enquanto o lia - já porque a gente que ele tratava, gente de matos e de grotas, de roças e capinzais, era também em Angola aquela com quem durante muitos anos andei a lidar pela via do ofício de viver (CARVALHO, 2006, pp. 107-108).

A ênfase no reconhecimento é tocante: afinal, Angola e Brasil se reencontram em sua leitura, como irmãos separados que de repente se reúnem em ocasião imprevista e surpreendente. Há, contudo, uma ideia que me interessa destacar: a sugestão de que a escrita de Rosa era propícia para tratar de certa realidade angolana, que era a vivida e testemunhada por ele, o leitor Ruy Duarte de Carvalho. Então pergunto: haveria uma vibração particular, uma força surgindo das estratégias de composição rosianas? De outra maneira: o que o leitor angolano pôde ouvir teria sido o som das "linguagens do mato", este perturbador "rosnar do sertão" de que nos fala Hansen? Seria, então, decisiva a escolha por fazer soar a fala do sertanejo e torcer em silêncio a fala do senhor doutor? Seria a possibilidade de se ouvir nesta escrita a voz do outro (este outro que seria pensado e discernido pelo próprio Ruy Duarte de Carvalho, como vimos)? Estaríamos diante da mimesis, aquele evento tão perigoso de que nos falava Platão?

Se pudermos dizer que sim, que estamos diante da mimesis como experiência de deslocamento e reinvenção de si, particularmente 
implicada no abalo de hierarquias sociais vigentes, ${ }^{10}$ devemos lembrar que a mimesis é uma questão de discurso - de composição discursiva, da posição das falas, ou seja, envolve o seu modo de relacionamento. Vozes recalcadas - desqualificadas pela cultura letrada dominante - se fazem presentes na ficção rosiana, instaurando uma perturbação pelo modo como surgem. Mas se essa perturbação resulta de construção literária, é resultado também, certamente, da leitura/escuta. Como significar essa fala de Riobaldo, quais seus sentidos? Nada está pronto. Afinal, se a mimesis nos diz do inacabamento de toda pessoa, nos diz também do inacabamento de todo discurso literário. É preciso uma disponibilidade de leitura/escuta inventiva para que a experiência da mimesis se faça. Esta abertura é muitas vezes restringida pela força das hierarquias vigentes, pela rigidez dos papéis prontos, já dados, vividos no comum do dia a dia (em particular em sociedades violentas e desiguais como as de base colonial).

Investigando a linhagem regionalista da literatura brasileira, Antonio Candido, no ensaio "A literatura e a formação do homem" (1972), defende que suas formas surgem "do contato entre o europeu e o meio americano" (1999, p. 86). Em sua perspectiva, no regionalismo brasileiro poderíamos encontrar formas humanizadoras e reificadoras, correspondendo a duas possíveis funções da literatura, a função humanizadora (valorizada pelo autor) e a função reificadora (que, no caso, consiste na reposição e reforço de estereótipos negativos a respeito do homem do interior).

1o Se Platão reconhece a força perturbadora da mimesis, apontando a intensa experiência emocional que proporciona, não supõe um desdobramento transformador envolvendo distanciamento crítico. A transformação/metamorfose da mimesis é, para Platão, sempre irrefletida, irracional, pura repetição dos padrões de comportamento representados. Estou já, é evidente, lidando também com as proposições de Luiz Costa Lima acerca da experiência mimética, supondo, portanto, um jogo dinâmico entre adesão (ao outro) e distanciamento (de si), entre semelhança (do objeto representado com um suposto mundo) e diferença (com relação a este mesmo mundo, sendo esta diferença a condição mesma do ficcional). 
Como exemplo de reificação, analisa o conto "Mandovi", de Coelho Neto; já com função humanizadora, o conto "Contrabando", de Simões Lopes Neto. Os efeitos contrários resultam do modo de se construir a fala dessa personagem interiorana: se em Coelho Neto a fala do caipira é marcada como desvio (o discurso do narrador se faz no português padrão culto e será contraposto ao discurso da personagem, em português estropiado pela marcação fonética); em Simões Lopes Neto haveria uma convergência entre norma culta e falar gaúcho, na voz integradora do narrador-personagem Blau Nunes. Assim, se no conto de Coelho Neto são repostas hierarquias entre cidade e campo (na perversa distinção entre fala marcada e não marcada), ${ }^{11}$ no conto de Simões Lopes Neto, a estratégia de representação da fala do gaúcho resulta de interesse, pois aproxima o "homem rústico" do "homem culto".

O estudioso propõe duas experiências contrastantes: o reforço de preconceitos na desqualificação da fala caipira; a ampliação, pela leitura, da humanidade do leitor. No caso negativo, clara hierarquia se instala entre os discursos, sendo que o leitor se verá levado a se identificar com a voz narrativa, apresentada como correta, e a rir maldosamente da fala da personagem, ou, benevolente, a lamentá-la; no caso positivo, em que a literatura realiza sua função humanizadora, o que se passa é um movimento do leitor urbano em direção à personagem interiorana, identificando-se com sua fala (não estropiada, mas levemente diferente) e ampliando sua própria experiência de humanidade ao compreender, como competente, uma fala diversa da sua. Se no primeiro caso há reforço e enrijecimento dos lugares e modos de fala estabelecidos; no segundo, há movência, trânsito e contato com o diverso. Então, pergunto: se reificada a fala alheia, a mimesis se interrompe? Se esta fala representada convida à identificação e, consequentemente, a um deslocamento (o leitor sendo conduzido para fora de si, dos lugares de fala que já cultiva e valoriza em sua vida mesma), então haveria a mimesis?

Na proposição de Candido, o que se apresenta como decisivo é o modo como o leitor se volta para as falas representadas, num jogo entre o

11 Antonio Candido aponta o tratamento desigual na representação dos modos de falar o português, pois a fala do narrador, no conto de Coelho Neto, não sofre a mesma evidenciação do nível fônico que a fala do caipira. Afinal, se deve representar a fala daqueles que integram certo grupo de letrados do Rio de Janeiro, deveria ser igualmente carregada de marcas (1999, p. 89). 
convite destas vozes (pela maneira como são representadas e organizadas nos contos) e os lugares de fala socialmente marcados que o leitor conhece previamente e reconhece na leitura. Assim, este leitor não é um leitor abstrato, surge integrado a um contexto histórico-social específico em que certa norma linguística é valorizada e associada à fala de certos grupos (mesmo que esta associação mascare a realidade linguística mesma). Trata-se de um leitor urbano culto. É este leitor que, tendo aprendido o valor de certa norma, tende a se identificar com ela e rejeitar o diverso. Portanto, a mimesis se frustra porque o leitor reconhece em si e no narrador de Coelho Neto os lugares e modos de fala já estabelecidos como superiores. É então que o movimento em direção à fala e ao ponto de vista do caipira se interrompe.

Já em Simões Lopes Neto o homem do interior não surgiria tão radicalmente outro (e inferiorizado por não fazer uso de uma fala tida como competente). Ausente a voz autorizada do narrador culto, representa-se apenas a fala do gaúcho, com direito a se integrar à norma culta, levemente estilizada. Assim, o mover-se do leitor se daria pela sutileza da representação: a fala representada do gaúcho converge com aquela que o leitor urbano entende como competente. Mas, importa frisar, para Candido, as falas em jogo (urbana/culta e gaúcha) não coincidem completamente. A fala do gaúcho surge como uma fala outra (ligeiramente outra) representada como igualmente competente (por isso integrada a um registro literário culto), e é por tal inscrição da fala gaúcha na norma culta que o deslocamento da mimesis se instala. Será, então, que para haver mimesis, deve haver convergência de vozes e linguagens? Este resultado seria muito diferente da proposição platônica, como vimos. Como avançar?

Bakhtin destaca a importância das hierarquias internas à obra e do pano de fundo: a relação dialógica pode surgir representada no próprio texto literário (é o caso do romance polifônico, sendo, então, decisiva a plenivalência das vozes, ou seja, a relação não hierárquica entre as mesmas), mas pode também ter o segundo termo ausente, contudo, recuperável pelo leitor (este sempre situado nalgum contexto específico, com seu repertório prévio que colocará em ação). Talvez os casos estudados por Candido demandem a articulação destes dois momentos. A hierarquia instalada no conto de Coelho Neto, interna, é reposição das hierarquias vigentes, tendo um pano de fundo que não se perspectiva, reforça-se; já a convergência do conto de Simões Lopes Neto entre 
a norma culta e o falar gaúcho teria como pano de fundo o contraste experimentado socialmente (por certo leitor, em certa época e lugar), de maneira que essa quase monotonia é multiplicada, ganhando pelo menos uma tonalidade a mais. Teríamos, então, fixidez e mesmidade na aparente duplicidade; e mobilidade e diferença na aparente univocidade.

Ainda que viável, esse avanço no tratamento da mimesis não me parece suficiente. Resta lidar com um pano de fundo teórico: a hierarquia prevista na distinção entre "homem culto" e "homem rústico" na teorização de Candido. Isso porque talvez a aposta na convergência, na incorporação do falar gaúcho à norma culta, conviva com certas apostas na literatura, entendida como veículo de integração nacional e de progresso. Decisiva na construção da nação, a literatura participaria da formação de uma cultura válida no país - a um só tempo brasileira (portanto, incorporando seus diversos elementos locais/particulares, dentre os quais o caipira e o gaúcho) e civilizada (ou seja, integrada ao concerto das modernas nações civilizadas do Ocidente, portanto, numa determinada gramática de matriz europeia assumida como moderna). ${ }^{12} \mathrm{O}$ homem culto, formado no seio da urbanidade civilizada, deve, então, acolher e incorporar o homem rústico, cuja existência se dá nas margens ou fronteiras desta civilização. Assim, temos subjacente às categorias "homem culto" e "homem rústico" uma concepção normativa de cultura. Surge a dúvida: e se o movimento ocorresse na direção inversa, se a fala do gaúcho desestabilizasse a tal norma culta (associada ao falar do erudito/urbano)? A melhor formulação da pergunta seria: se a categoria "homem culto" se multiplicasse para além da cultura letrada urbana de matriz europeia, quais seriam as consequências?

Em sua trilogia Os filhos de Próspero, Ruy Duarte de Carvalho recorre à autoficção: ${ }^{13}$ faz-se narrador-personagem que pode ser reconhecido como o autor sem, contudo, resvalar para a autobiografia.

\footnotetext{
12 Recupero momentos do prefácio à segunda edição da Formação da literatura brasileira, de 1961 (1964, p. 18).

13 Sonia Miceli aponta que o próprio Ruy Duarte de Carvalho reconheceu sua escrita como autoficcional (MICELI, 2011, p. 29).
} 
Recursos metalinguísticos são amplamente mobilizados - encenandose a própria escrita, o processo de invenção das estórias, além de serem evidenciados os suportes (ficcionais também) desta escrita - cadernos, diários, livros, e-mails etc. Gostaria de destacar, especialmente, que a estratégia de evidenciação da escrita (seus processos e suportes) associa-se a uma permanente representação de situações de diálogo. O narrador-personagem se empenha, nos três volumes da trilogia, em relatar conversas presenciais ou mediadas (por e-mails, por exemplo), dedica-se a apresentar (ordenar de alguma maneira) a fala do outro que lhe foi dirigida. Sua fala, também, ao ser recuperação de fala alheia, é ela própria sempre dirigida a alguém. Há recuperação e endereçamento de discursos, ou seja, atravessamentos entre as instâncias do eu e do outro. Processo em que um jogo de espelhos produzirá deslizamentos e contaminações: personagens se fazem duplos do narrador (que já é um narrador-personagem que se apresenta como o próprio autor), problematizando-se os contornos entre mimesis (fala alheia) e diegesis (fala própria).

A trilogia Os filhos de Próspero se inicia com Os papéis do inglês (2000), romance que encena sua própria escrita (na sugestão de e-mails e fragmentos datados), envolvendo, como elemento central da trama, também uma escrita: a reinvenção da crônica "O branco que odiava as brancas”, de Henrique Galvão. Esta estória que se monta aos poucos será uma espécie de transfiguração da vida do narrador-personagem, de modo que Archibald Perkings (o protagonista) torna-se seu duplo. Assim, se num primeiro momento podemos supor a predominância da diegesis, na presença ostensiva de uma voz narrativa, numa leitura mais atenta percebemos que a instância da mimesis impregna o próprio relato - a fala do narrador perde o lastro com uma identidade estável. Estamos diante de metamorfose e deslocamento, traços da mimesis - ou seja, ao invés do uno diegético, o múltiplo mimético.

A predominância da voz narrativa ressurge nos outros dois romances da trilogia. Da mesma maneira que n'Os papéis do inglês, n’As paisagens propícias (2005) e n'A terceira metade (2009) o autor envolve-se em complexa dinâmica de duplicação e autoficcionalização (tornando-se novamente narrador-personagem). Assim, o que seria da ordem do relato toca a mimesis, produzindo-se a indefinição entre as posições do eu e do outro. Se a diegesis garantiria, para Platão, segura distância entre o que se é e o ser alheio, na trilogia como um todo o "eu" se multiplica já que surge 
com o outro, pelo outro, e como outro. N’As paisagens propícias, será a interlocução com Severo que se tornará central na trama. Severo tem traços desse autor-feito-narrador-personagem, como tinha Archibald Perkings no primeiro romance. Contudo, agora ambos estão no mesmo plano narrativo, tendo se conhecido e estabelecido o diálogo que é apresentado como material discursivo de que se faz o livro. N'A terceira metade, o empenho do narrador-personagem é também relatar o que uma personagem, Trindade, teria lhe contado. Novamente, trata-se de apresentar a composição do livro como convivência com discursos alheios. ${ }^{14}$

O livro As paisagens propícias se apresenta como esforço de ordenação do relato da personagem Severo em conversa e através de e-mails. O momento da transcrição destes e-mails seria, talvez, o momento mais evidente da mimesis: surge a representação da fala da personagem, marcada, inclusive, por um inusitado recurso a pontos cujo objetivo seria traduzir o ritmo da oralidade. O computador (esta máquina) teria permitido, na visão de Severo, solucionar um problema da escrita, a ausência de marcas para os silêncios que pontuam as conversações em presença. Temos algo que pode parecer reticências, mas não é. São pontos que devem aludir ao tempo da fala e seus silêncios, ou seja, a escrita se afeta pela máquina e pelo corpo. Surpreendentemente, o narrador vai incorporar esta estratégia, de modo que sua própria fala será, a partir de então, marcada por pontos/silêncios. Se considerarmos que no livro terceiro da trilogia e em textos não ficcionais do escritor tal recurso será mantido, somos levados a notar que os contornos entre autor, narrador e personagens tendem a se esfumar. ${ }^{15}$

14 É importante notar que tanto Severo como Trindade leram textos do "autor" - Severo diz ter lido trabalhos sobre os pastores kuvale (ver Vou lá visitar pastores); Trindade conheceria poemas seus (por sua vez baseados em poesia oral africana; ver Lavra alheia I [Ondula, savana branca] e Lavra alheia II [Observação directa], em Lavra). Assim, as personagens participam ativamente de uma dinâmica de leitura, escrita, fala e escuta (que envolve ampla rede de textos escritos e orais). Na trilogia, as interações são representadas como horizontais e não hierárquicas - as posições entre os interlocutores (entre o eu e o tu) se alternam dinamicamente.

15 Este é o caso, por exemplo, do texto citado anteriormente: “Tempo de ouvir o 'outro' enquanto o "outro" existe, antes que haja só o outro... Ou pré-manifesto neo-animista”, de 2008. Lembremos que a autoficção se consitui justamente do atravessamento entre os domínios da ficção e da não ficção. É interessante notar que passagens deste texto são transcritas no final do último livro da trilogia, A terceira metade, remetendo a ideias de Severo (pp. 398-399). 
Penso que essa representação em vertigem de palavras, posições e identidades trocadas deve ser lida como parte de uma conversa em curso: o diálogo entre discursos ocidentais (literários, científicos, filosóficos) e discursos extraocidentais, cujas categorias nos escapam. De outra maneira: todo o excessivo material discursivo que compõe a trilogia (e que a ultrapassa, esparramando-se para além do continente de seus volumes) é palavra afetada pela palavra do "OUTRO" (como delineado pelo próprio Ruy Duarte de Carvalho em texto já citado). Minha proposição é a de que a interlocução permanente com Paulino, o amigo assistente, marca uma interação decisiva (para além daquelas que estão em primeiro plano). Como em Grande sertão: veredas, em que apenas um lado do diálogo se apresenta (já rico em interlocuções diversas), toda escrita de Ruy Duarte de Carvalho supõe um diálogo-base, de que só temos uma parte. A fala de Paulino não se representa para além de uma espécie de mote que se repete: "Não vale a pena" (já numa fala relatada pelo narrador, indireta). ${ }^{16}$ Na verdade, a representação, a mimesis, da fala dos pastores não é o foco da trilogia. $\mathrm{O}$ que se representa é seu efeito em outras falas, em decorrência da interação. Assim, tanto o autor-feito-narrador-personagem como Perkins, Severo e Trindade (as personagens centrais) interagem com os pastores kuvale e outros povos que habitam o sul de Angola, tendo suas vidas - e falas - implicadas em tal convivência.

Trindade talvez seja a personagem que mais vinculada esteja ao "OUTRO" (como delineado por Ruy Duarte de Carvalho). Sua vida é marcada pela origem mucuíssa: "Trindade é negro, sim, mas é mucuísso, não é banto de origem........ e no contexto em que sempre viveu nunca deixou de ser-lhe lembrado, tanto por brancos como por negros, que sua 'raça' é a de um twa, de um vátua, de um primitivo pré-banto, domesticado

16 N'A terceira metade, o leitor é levado a entender que Paulino morre de repente, esta seria a "má notícia" que teria liquidado todos os programas (p. 173). De fato, o narrador é suspenso, pois não tem mais destinatário. Vemos, assim, que a posição de narrador associa-se a uma situação de oralidade: conversar com Paulino. O livro será, a partir de sua morte, tarefa apenas do autor (que virá a se dirigir a Severo). Terminado o livro, o leitor encontra dedicatória à memória de Paulino e Felipe (destinatário de livro anterior, Vou lá visitar pastores), "ambos falecidos em Moçâmedes, no Namibe, já depois deste livro ter começado a ser escrito". É curiosa essa distinção entre "autor" e "narrador" que surge n'A terceira metade (p. 30 e outras). O "narrador" se apresenta como uma função, a de ordenar narrativamente um material discursivo que o "autor" teria recebido. Trata-se, de recuperar e reforçar um gesto já presente n’As paisagens propícias (ver pp. 154, 175 e 202). 
tanto pela incidência banta como pela incidência ocidental" (2009, p. 23). Criado pela mãe, é apenas com oito ou nove anos que sofrerá um processo de ocidentalização (quando se torna empregado de uma família abastada de colonos), e, a partir dos dezoito anos, de bantuização (ou seja, de integração ao modo de vida dos pastores kuvale), seguido de novos trabalhos (como cozinheiro, especialmente de viajantes - engenheiros, geólogos, escritores etc.) e de um mergulho na cosmovisão banta através do convívio com o amigo Tom (que será citado repetidamente dada sua fina capacidade de elaborar aforismos), de modo que Trindade se constrói na interação com diferentes culturas. ${ }^{17}$ Aprende português ainda na infância, sendo nesta língua que virá a travar, já em idade avançada (com mais de oitenta anos), conversa com o narrador-personagem. Como Riobaldo, que transita entre diferentes camadas e grupos sociais do interior do Brasil, Trindade atravessou mundos que se entrechocam em Angola (e para além de suas fronteiras). Contudo, se em Grande sertão: veredas temos a representação da fala de Riobaldo; n'A terceira metade, temos o relato da fala de Trindade feito pelo narrador-personagem ou seja, não é Trindade quem fala diretamente (há, contudo, breves momentos em que o narrador nos apresenta sua fala na primeira pessoa, particularmente na parte final do livro, sem, contudo, marcar alguma diferença de linguagem). Lembremos que o narrador se apresenta como o próprio autor, um antropólogo, um "senhor doutor". De certa maneira, é como se o livro de Ruy Duarte de Carvalho fosse uma continuação de Grande sertão: veredas: tendo ouvido tanto, o que faria o "senhor doutor" com aquela transbordante fala? Qual seria a sua fala depois daquela escuta? Como ela se apresentaria? A quem?

\section{6}

Em conferência apresentada em Coimbra em 2005, intitulada "Falas \& vozes, fronteiras \& paisagens... escritas, literaturas, entendimentos...”,

\footnotetext{
17 O narrador explica: “ .será esse seu amigo Tom quem lhe irá introduzir mais tarde Namíbia abaixo, e essa incursão austral até ao Cabo das Agulhas é que acabará por colocar Trindade na condição e na situação de produzir rezas. ." (2009, p. 174) As rezas de Trindade estão implicadas na própria trama do romance (2009, pp. 18, 417, e 421-2) e se associam à poesia de Ruy Duarte de Carvalho (2005b).
} 
Ruy Duarte de Carvalho desenvolve considerações sobre a escrita rosiana, algumas das quais integrariam Desmedida. Afirma:

O talento que permitia a Guimarães Rosa e a José Luandino Vieira escreverem daquela maneira pertence, quanto a mim, àquele tipo de talentos que nos leva a dizer, quando vemos por exemplo Gilberto Gil ou Ronaldinho Gaúcho dançarem num palco ou num estádio, que quem é bom já nasce ensinado (CARVALHO, 2008, p. 14).

Tem sido frequente a atenção de estudiosos a possíveis convergências entre as estratégias de composição de Luandino Vieira e as de Guimarães Rosa. Já o diálogo de Ruy Duarte de Carvalho com Rosa tem sido pouco explorado no que se refere à composição, como se não existissem estratégias convergentes. Proponho, contudo, que sim, que a singular estrutura de diálogo de Grande sertão: veredas é reinventada pelo escritor angolano, ou desdobrada de modo que o lado do "senhor doutor" se apresente, numa fala já transtornada pela interação em curso. $\mathrm{O}$ escritor angolano continua:

Ao mesmo tempo, porém, que a minha paixão pela escrita de GR e a minha
rendição ao gênio de escritas afins me elucidava sem lugar para equívocos
que a minha via, vindo um dia a escrever, jamais nem poderia passar por ali,
também a isso devo a percepção simultânea de que a validade e os terrenos
da literatura não poderiam reduzir-se a contorcionismos sintáticos nem a
pirotecnias lexicogênicas, que era o que de mais brilhante, fulgurante mesmo,
de imediato se revelava ali como mais tonificante para uma talvez cansada e
despotencializada escrita em português que era preciso reinventar para poder
servir-nos a nós, angolanos.............. que uma literatura manifestamente
diferenciada não tem necessária e obrigatoriamente que passar por recursos
dessa ordem. Muito boa e diferenciada literatura, e até latino-americana e
africana, não recorre a isso, ou ocorre sem que tal se imponha de maneira tão
gritante...... e se GR é de fato um grande escritor não é seguramente só por isso,
é porque no que escreve entra aquilo de que se fazem as grandes literaturas,
que é a adequação da palavra à condição da experiência, das percepções e da
consciência do sujeito em situação interativa (CARVALHO, 2oo8, p. 15).

Talvez, caso o trabalho de escrita se resuma, como diz Ruy Duarte de Carvalho, ao de "inventar onomatopeias, permutar prefixos e sufixos, inverter categorias gramaticais, multiplicar formas terminativas" (2008, p. 15), possamos estar diante de algo semelhante àquela estratégia de marcação fonética da fala caipira criticada por Candido - ou seja, diante da reificação da fala da personagem e da própria personagem. Para o escritor angolano, decisivas não são as estratégias fulgurantes ("contorcionismos 
sintáticos" e "pirotecnias lexicogênicas"); decisivo é o modo como estas estratégias se associam a algo mais fundamental, apresentado em termos de adequação da palavra à situação interativa do sujeito, a sua experiência e consciência. ${ }^{18}$ Nesse sentido, a escrita de Ruy Duarte de Carvalho carrega o que foi lido como crucial em Rosa, fazendo-se também uma palavra viva, dialógica.

Em Grande sertão: veredas desaparece a figura do narrador associada ao autor (o letrado urbano, o "homem culto" de que fala Candido); o "senhor doutor" se inscreve no romance como personagem silenciosa. Não há discurso que possa ser lastreado e tomado como o do autor, como aquele que teria saído da boca de Guimarães Rosa - estamos, portanto, diante da pura mimesis. Minha sugestão é a de que a diegesis de Platão, entendida como a fala do poeta, exige um lugar enunciativo socialmente reconhecido. A possibilidade de amarrar certa voz narrativa ao poeta decorre de convenções partilhadas. Assim, penso que o poeta Homero referido n'A República alude, na verdade, a um papel social. Do mesmo modo, o lastro entre narrador e autor sugerido por Candido como recorrente na ficção regionalista brasileira supõe o reconhecimento de um lugar social específico, o do escritor (o letrado urbano, o "homem culto"). Trata-se também de um papel a ser desempenhado, o de representante da norma culta, da fala aceita e reconhecida como correta e competente.

Se podemos assim pensar, a diegesis demanda, para se instalar, de convenções que permitam a costura entre o discurso do narrador e certo discurso reconhecido como do próprio autor. Quando tal lugar de fala é abalado, o discurso do autor surge em sua opacidade, a diegesis é perturbada pela mimesis. Assim, caso o laço se desate, o que era diegesis surge como mimesis: o autor se concretiza, ocupa um lugar de fala entre outros, é colocado no mesmo plano das personagens. Tal seria o caso, parece-me, do romance polifônico como teorizado por Bakhtin. Seria, também, o caso do singular diálogo de Grande sertão: veredas, em que o papel a ser desempenhado pelo "senhor doutor" é o da escuta. Penso que a autoficção repõe a inscrição do autor no mesmo plano das personagens - sua fala não encontra em que se ancorar, sua pessoa mesma surge como persona, invenção. A força da mimesis, temida por Platão, mostra-se

18 Bakhtin aponta que, em termos puramente linguísticos, haveria pouca diferenciação em Dostoiévski (2013, p. 208). 
radical: a pessoa surge em sua plasticidade, em processo, portanto, de metamorfosear-se, fazer-se múltipla.

Há, porém, um traço da diegesis que se reforça ao longo da trilogia autoficcional de Ruy Duarte de Carvalho. Platão entendia, como vimos, que a diegesis garantiria uma segura distância, do poeta e de seu público, quanto às ações das personagens (evitando-se os perigos de identificação e envolvimento emocional). Se, porum lado, a diegesis n'Os filhos de Próspero se transtorna pela presença do autor como narrador-personagem (ou seja, por sua concretização e inscrição na própria trama ficcional); por outro, ressurge pelo resvalar no argumentativo e no historiográfico, ou seja, pela diluição da cena, das situações concretas. Entendo que tal trânsito para o analítico, que pode ser associado ao distanciamento próprio da diegesis, merece atenção. Mesmo que arriscando despotencializar os efeitos de identificação próprios da mimesis, há um possível ganho nessa estratégia: o próprio pensamento ocidental é colocado em perspectiva, ou seja, não apenas o escritor, mas também o filósofo e o cientista têm seu discurso tornado opaco, inscrito numa interação dialógica, perturbando-se apostas de incorporação do "OUTRO" em abordagens tanto literárias como científicas e filosóficas. Trata-se, assim, do recurso à autoficção, à diegesis perturbada pela mimesis, para que certas atribuições de competência, implicadas em processos coloniais e projetos modernizantes, sejam subvertidas. O papel social do letrado (reconhecido no mundo ocidental e ocidentalizado como agente de civilização/modernização, seja como escritor, seja como cientista ou filósofo) surge em crise. Ruy Duarte de Carvalho empenha-se na proliferação da categoria "homem culto", pois o discurso tido como competente se verá multiplicado para além dos espaços e modos ocidentais. Não há integração da fala do "OUTRO” a uma norma ocidental (tampouco a certo registro literário tido como culto - tal seria, para Candido, o caso do falar gaúcho em Simões Lopes Neto); há o desfazimento desta norma pelo convívio, pela interação com culturas outras, com suas próprias concepções e topografias discursivas. O diálogo de fundo com Paulino tem, parece-me, força de desmonte.

\section{REFERÊNCIAS BIBLIOGRÁFICAS}

ADORNO, Theodor. Notas de literatura I. Trad. Jorge de Almeida. São Paulo: Duas Cidades; Editora 34, 2003. 
BADIOU, Alain. A República de Platão (recontada por Alain Badiou). Rio de janeiro: Zahar, 2014.

BAKHTIN, Mikhail. O discurso no romance. In: Questões de literatura e estética (A teoria do romance). São Paulo: Editora da Unesp, 1998.

BAKHTIN, Mikhail. Problemas da Poética de Dostoiévski. Rio de Janeiro: Forense Universitária, 2008.

CANDIDO, Antonio. Formação da Literatura Brasileira: momentos decisivos (v. I). São Paulo: Martins, 1964.

CANDIDO, Antonio. Jagunços mineiros de Cláudio a Guimarães Rosa. In: Vários escritos. São Paulo: Livraria Duas Cidades, 1977.

CANDIDO, Antonio (1972). A literatura e a formação do homem (1972). In: Remate de Males. Número Especial Antonio Candido. Campinas: IEL-Unicamp, 1999, pp. 81-9o.

CARVALHO, Ruy Duarte de. Os papéis do inglês. São Paulo: Companhia das Letras, 2007.

CARVALHO, Ruy Duarte de. As paisagens propícias. Lisboa: Cotovia, 2005 a.

CARVALHO, Ruy Duarte de. Desmedida. Rio de Janeiro: Língua Geral, 2010.

CARVALHO, Ruy Duarte de. A terceira metade. Lisboa: Cotovia, 2009.

CARVALHO, Ruy Duarte de. Vou lá visitar pastores. Lisboa: Cotovia, 1999.

CARVALHO, Ruy Duarte de. Lavra (poesia reunida 1970/200o). Lisboa: Cotovia, 2005b.

CARVALHO, Ruy Duarte de. A câmera, a escrita e a coisa dita... Lisboa: Cotovia, 2008.

CARVALHO, Ruy Duarte de. Tempo de ouvir o 'outro' enquanto o “outro” existe, antes que haja só o outro... Ou pré-manifesto neo-animista. Texto disponível no site Buala (Acesso 31/5/2015): http://www.buala.org/pt/ruy-duarte-de-carvalho/tempo-deouvir-o-outro-enquanto-o-outro-existe-antes-que-haja-so-o-outro-ou-p.

COSTA LIMA, Luiz. Representação social e mimesis. In: Dispersa demanda. Rio de Janeiro: Livraria Francisco Alves, 1981.

COSTA LIMA, Luiz. Persona e sujeito ficcional. In: Pensando nos trópicos. Rio de Janeiro: Rocco, 1991.

COSTA LIMA, Luiz. Mímesis: desafio ao pensamento. Rio de Janeiro: Civilização Brasileira, 2000.

FOUCAULT, Michel. O que é o autor? In: Ditos e Escritos; Estética: Literatura e Pintura, Música e Cinema. Motta, Manuel Barros da. (org). Rio de Janeiro: Forense Universitária, 2001. 
FRIEDMAN, Norman. O ponto de vista na ficção. In: Revista USP, n. 53, março/maio 2002.

GALVÃO, Henrique. O branco que odiava as brancas. In: Em terra de pretos. Lisboa: Aillaud \& Bertrand, 1929.

GENETTE, Gérard. Fronteiras da narrativa. In: BARTHES, Roland et alii. Análise estrutural da narrativa. Petrópolis: Editora Vozes, 2011.

HANSEN, João Adolfo. O ó: a ficção da literatura em Grande Sertão: Veredas. São Paulo: Hedra, 2000.

ISER, Wolfgang. O Fictício e o Imaginário: Perspectivas de uma Antropologia Literária. Rio de Janeiro: Ed. UERJ, 2013.

MICELI, Sonia. Contar para vivê-lo, viver para cumpri-lo: autocolocação e construção do livro na trilogia ficcional de Ruy Duarte de Carvalho. Dissertação de Mestrado. Universidade de Lisboa, 2011.

MORIN, Edgar. Saberes Globais e Saberes Locais: o olhar transdisciplinar. Rio de Janeiro: Garamond, 2010.

PLATÃO. A República. Lisboa: Fundação Calouste Gulbenkian, 2012.

ROSA, João Guimarães. Grande sertão: veredas. Rio de Janeiro: Editora Nova Fronteira, 1986. 